Schäfer, A.I. ; Mauch, R. ; Fane, A.G. ; Waite, T.D. (2002) Charge Effects in the Fractionation of Natural Organics using Ultrafiltration, Environmental Science \& Technology 36, 2572-2580. DOI: $10.1021 /$ es0016708

\section{Charge Effects in the Fractionation of Natural Organics using Ultrafiltration}

submitted to

Environmental Science \& Technology

Andrea I. Schäfer ${ }^{(1), 2^{*}}$, Rainer Mauch ${ }^{1,3}$, T. David Waite ${ }^{2}$, Anthony G. Fane

${ }^{1}$ School of Chemical Engineering and Industrial Chemistry, UNESCO Centre for Membrane Science \& Technology, University of New South Wales, Sydney NSW 2052, Australia

${ }^{2}$ School of Civil and Environmental Engineering, Centre for Water and Waste Technology, University of New South Wales, Sydney NSW 2052, Australia

${ }^{3}$ Fakultät für Verfahrenstechnik und Technische Kybernetik Pfaffenwaldring 9, 70569 Stuttgart, Germany

*Author to whom correspondence should be addressed; tel: +61-2-9385 4470; fax: +61-2-9385 6139; email: a.schaefer@unsw.edu.au

\section{Abstract}

Comparison of two commonly used techniques for molecular weight determination of natural organics, UF fractionation and high performance size exclusion chromatography (SEC), show that neither technique gives absolute measures of molecular weight. Investigations of both International Humic Substances Society standard humic and fulvic acids as well as natural organic matter concentrated from surface freshwaters show that charge effects and solution conditions are important in both SEC and UF fractionation with various components of the natural organics being affected differently. Membranes with a smaller molecular weight cut-off produce permeates with a lower UV/DOC . lower UV/DOC ratio suggesting that the more aronatic components of natural organics are removed by the lower molecular weight cut off membranes. Vanation in ionic strength has little effect on the rejection of humic acid fractions but does significantly influence the rejection of low molecular weight acids. $\mathrm{pH}$ and organic concentration do not affect DOC rejection significantly over the $\mathrm{pH}$ range 4.5 to 10 and the DOC concentration range of 15 to $60 \mathrm{mgL}^{-1}$. These results indicate that UF should not be applied for quantitative "size" analysis unless operated under welldefined conditions. If operated under conditions appropriate to water treatment, UF fractionation can give information of direct applicability to treatment such as the MWCO required to achieve significant organics removal.

KEYWORDS: fractionation, humic substances, membranes, natural organic matter, size exclusion chromatography, ultrafiltration, water treatment 


\section{Introduction}

Ultrafiltration (UF) is a membrane process whereby solutes are retained, for the most part, by size exclusion. This fact renders UF suitable as an analytical tool for molecular weight determination or as a preparative method to investigate characteristics of different molecular weight fractions. Retention is also affected however by the geometric properties of pores and their size distribution, solute-membrane interactions and concentration polarisation effects (1). For example, to reduce losses of organics by adsorption of natural organic matter (NOM), the membrane material should be hydrophilic (e.g. regenerated cellulose rather than polysulfone) and the pore size distribution should be narrow to obtain good size fractionation (2).

The reported molecular weight cut-off (MWCO) of commercial membranes is usually determined The reported molecular weight cut-off (MWCO) of commercial membranes is usually determined
by the manufacturer using uncharged molecules such as dextrans at relatively high concentrations (3), (4). These molecules are not necessarily very similar to the compounds of interest, so the rejection characteristics of the two groups of molecules could be drastically different.

UF fractionation is commonly used to determine the molecular weight of natural organics (5-17) with a variety of filtration protocols used in these fractionation experiments. Cells have been refill the cell with pure water to keep the cell volume constant (diafiltration). All these factors could influence the results obtained, as could solution chemistry, $\mathrm{pH}$, and ionic strength. Generally, the reported molecular weight results are larger than the molecular weights of fulvic acid (FA) and humic acid (HA) determined by other methods.

Collins et al. (18) used five stirred UF cells in parallel to determine the apparent MW of humic substances (HS). Shaw et al. (9) showed that larger compounds appeared in the permeate in a UF system than when the same membrane was used in dialysis mode, suggesting that distortion of the organic mocules under shear in UF allowed passage of larger molecules. Aiken (13) used two different UF membranes to determine the MW of FA. Aiken noted in his review that researchers using a hydrophilic membrane observed that $50 \%$ or more of FA were greater than $10 \mathrm{kDa}$, whereas researchers using a more hydrophobic membrane found a significantly lower proportion (3-36\%) This indicates the importance of solute-membrane interactions. Standards of MW 2000 and 5000 were mostly retained by the $10 \mathrm{kDa}$ MWCO membranes.

Aster $e t$ al. (19) set-up an analytical, multistage ultrafiltration system to allow the on-line separation of aqueous HS into six MW fractions and Burba et al. (10) extended this method to metal-organic complexes, both developing UF into an analytical tool.

Membrane filtration competes with chromatographic techniques such as gel permeation Membrane filtration competes with chromatographic techniques such as gel permeation
chromatography (GPC) as an analytical technique for molecular weight fractionation. GPC relies on chromatography (GPC) as an analytical technique for molecular weight fractionation. GPC relies on
the fact that molecules that are smaller than the pore size of the gel matrix are retarded in their the fact that molecules that are smaller than the pore size of the gel matrix are retarded in their
passage through the column. Larger molecules which cannot penetrate pass through the column more rapidly (20). GPC depends on the MW standards used if a molecular weight is to be determined. It also depends on the electrophoretic mobility of the organics, which may vary with their molecular weight (21), (22). Adsorption effects and charge interactions may render quantitative analysis difficult (23). Both adsorption and electrostatic interactions have been used to gain further and electrostatic effects at low ionic strength. Chromatographic techniques are very commonly used in the characterisation of natural waters $(9,14,23,25-28)$. However, most authors use differen techniques, detectors, standards and eluents, making the comparison of results difficult. Perminova et al. (29) have overcome some of those difficulties in determination of 'absolute size' by testing many organics and modeling the size of humic substances. The structural approach, where standards of a similar structure to the compound of interest, rather than similar hydrophobic - hydrophilic characteristics proved most valuable. The ideal standard for humic substances was identified as sodium polystyrene sulfonates (PSS).

Given the complex nature of interactions involved, it is not surprising that different methods offer different results. Indeed, Leenheer (30) found little correlation between the apparent molecular weights (AMW) of NOM determined by UF and GPC. However, Ephraim et al. (31) found a positive correlation between the two methods. Other results indicated high MW compounds were recovered more effectively using UF than GPC (10). Amy et al. (14) determined that $\mathrm{pH}$ affects GPC more than UF and they reported larger AMW with GPC than UF. This result, which differs from most other studies, could be due to the choice of standards and eluent The effect of ionic environment is also important as noted by Kwak and Nelson (32) who reported that the retention of UF membranes was reduced significantly in $1 \mathrm{~mol} \mathrm{~L}^{-1} \mathrm{NaCl}$ indicating some possible electrostatic effect. Staub et al. (33) recommended an ionic strength greater than $0.1 \mathrm{~mol} \mathrm{~L}^{-1}$ to reduce charge effects in UF fractionation. It is unclear if these charge effects are due to changes in the conformation of the molecules or due to screening of electrostatic interactions.

To gain insight into chemical characteristics of various fractions, further characterisation is one avenue. For example, Newcombe et al. (34) found that the different fractions exhibited highly varying characteristics. The carboxyl group content was similar in all fractions, but a gradual transformation from high colour, a highly branched structure, and low carbohydrate content to rather long chain aliphatic compounds occurred from high to low MW fractions. O-alkyl carbon rather long chain aliphatic compounds occurred from high to low MW fractions. O-alkyl carbon
content (related to carbohydrates) decreased with a reduction of molecular weight, possibly indicating a higher degradability of high MW compounds. These results indicated that fractionation could not be explained based solely on molecular weight. Very similar trends were found for different freshwaters with the same method (17).

In this paper we seek to further clarify processes operating in the fractionation of natural organic matter by ultrafiltration by examining, under carefully defined conditions, the size fractionation of both International Humic Substances Society (IHSS) standard humic and fulvic acids and a complex non-fractionated organic substrate. Fractionation by a series of ultrafiltration membranes is performed and compared with the results of size exclusion chromatography. The results so obtained are used to develop procedures for the more reliable size fractionation of natural organic matter by membrane techniques.

\section{Materials and Methods}

Chemicals. Chemicals were of analytical grade and supplied by Ajax Chemicals, Australia. $1 \mathrm{~mol}$ $\mathrm{L}^{-1} \mathrm{NaOH}, \mathrm{HCl}$ and $\mathrm{NaCl}$ were used for $\mathrm{pH}$ and ionic strength adjustment. Calcium was introduced using a $20 \mathrm{mmol} \mathrm{L}^{-1} \mathrm{CaCl}_{2}$ stock solution and added last to the solutions to avoid precipitation. The using a $20 \mathrm{mmol} \mathrm{L}^{-1} \mathrm{CaCl}_{2}$ stock solution and added last to the solutions to avoid precipitation. The
sample matrix consisted of $1 \mathrm{mmol} \mathrm{L}^{-1} \mathrm{NaHCO}_{3}, 0.5 \mathrm{mmol} \mathrm{L}^{-1} \mathrm{CaCl}_{2}$ and $20 \mathrm{mmol} \mathrm{L} \mathrm{NaCl}^{-1}$ as a sample matrix consisted of $1 \mathrm{mmol} \mathrm{L}^{-1} \mathrm{NaHCO}_{3}, 0.5 \mathrm{mmol} \mathrm{L}^{-1} \mathrm{CaCl}_{2}$
background electrolyte in MilliQ water with a resistivity of $>18 \mathrm{M} \Omega / \mathrm{cm}$.

NOM and Humic Substances. A NOM stock solution was produced by concentrating surface water from the Mooney Mooney Dam (Brisbane Water National Park, NSW, Australia). MF and reverse osmosis (RO) were used for concentration. Suwannee River Stream Reference humic acid (HA) and fulvic acid (FA) (IHSS, USA) were also used. These organics have been extensively characterised (35) and prepared as $100 \mathrm{mgL}^{-1}$ organic carbon stock solutions by mixing the dry powder with MilliQ water without increasing the $\mathrm{pH}$. The solutions were stored at $4^{0} \mathrm{C}$ in the dark.

The NOM was also fractionated into humic and fulvic acid fractions using non-ionic macroporous (XAD) resin after the method of Leenheer (36), (37). Prior to XAD fractionation a stock solution of about $4 \mathrm{~g}$ NOM powder in $500 \mathrm{~mL}$ water was prepared, resulting in a solution concentration of 291 $\mathrm{mgL}^{-1}$ as DOC. The solution was desalted using an Amicon YC05 membrane (molecular weight cut-off $500 \mathrm{Da}$ ). According to Amicon, this (very tight) UF membrane retains large salts such as 
phosphates and sulphates, but does not retain a significant amount of smaller-sized salts. $310 \mathrm{~mL}$ of permeate were collected and discarded resulting in a loss of $5.0 \mathrm{mg}$ organics (as DOC). Thus, $2.5 \%$ of the organics could be considered smaller than the membrane pores. The salt content of the organics and their fractions is shown in Table 1.

Membranes. The fractionation experiments require membranes that are very poor adsorbents to reduce loss of organics on the membranes. The Millipore "PL series" meet this criterion and are available in seven MWCOs in the range from $1 \mathrm{kDa}$ to $300 \mathrm{kDa}$. The fractionation membranes selected were the PLAC, PLBC, PLCC, PLGC, PLTK, and PLHK types with MWCOs of 1, 3, 5, 10,30 , and $100 \mathrm{kDa}$, respectively. Prior to use, the membranes were soaked in $0.1 \mathrm{~mol} \mathrm{~L}^{-1} \mathrm{NaOH}$ for 30 minutes Q MilliQ also removed the glycerin sufficiently.

Filtration Equipment. All experiments were carried out in a magnetically stirred batch cell (volume of $110 \mathrm{~mL}$, membrane area $15.2 \cdot 10^{-4} \mathrm{~m}^{2}$ ) at a pressure of $100 \mathrm{kPa}$ (if not otherwise indicated), pressurised with nitrogen gas and stirred at $270 \mathrm{rpm}$ (measured with a Philips PR $9115 / 00$ stroboscope). Permeate flow rate was determined by timed measurement of permeate mass. Experiments were conducted at a temperature of $25 \pm 1{ }^{\circ} \mathrm{C}$.

Filtration Protocol. Pure water flux was measured after the filtration of $500 \mathrm{~mL}$ of MilliQ water prior to each experiment. The transmembrane pressure applied for fractionation was $300 \mathrm{kPa}$ for the $1,3,5$ and $10 \mathrm{kDa}$ membranes and $100 \mathrm{kPa}$ for the 30 and $100 \mathrm{kDa}$ membranes. Parallel fractionation was used with the same feed sample fed to the five membranes simultaneously Permeate and retentate were then collected for analysis. The feed volume was $100 \mathrm{~mL}$, but only 35 $\mathrm{mL}$ of permeate was collected in each test. The membranes were reused up to 5 times, and were stored in $0.1 \%$ sodium azide at $4^{\circ} \mathrm{C}$.

Inductively Coupled Plasma Atomic Emission Spectroscopy (ICP-AES). A Perkin Elmer Optima 3000 Spectrometer was used to determine the cation content of solutions. Samples and multi-element standards $\left(0,1,10\right.$ and $\left.100 \mathrm{mgL}^{-1}\right)$ were prepared in $5 \%$ nitric acid. All vials used were cleaned with $1 \mathrm{~mol} \mathrm{~L}^{-1}$ sulphuric acid.

UV/VIS Spectrophotometry. A Varian Cary 1E spectrophotometer was used to scan each sample from 190 to $500 \mathrm{~nm}$, with absorption at $254 \mathrm{~nm}$ used to calculate rejection.

Total Organic Carbon (TOC). Total organic carbon was measured with a Skalar 12 TOC Analyser. All glassware used was soaked in $5 \mathrm{~mol} \mathrm{~L}^{-1} \mathrm{KOH}$ for $24 \mathrm{~h}$ and then rinsed with water to remove any organic contamination.

High Performance Size Exclusion Chromatography (HPLC-SEC). Size exclusion chromatography (SEC) was performed according to the method of Chin et al. (38). A Shodex KW802.5 SEC column (Waters Corp., Milford, MA., USA) was used and a Waters liquid chromatography system consisting of the following components was used for the analysis: Water 501 high pressure pump, Waters 717 autosampler, InterAction column temperature control oven, Waters 484 UV/VIS detector and Waters Millenium 2.0 computer software package. The mobile phase consisted of $200 \mathrm{~mm}^{-1}$ phosphate at $\mathrm{pH} 6.8$. The eluent was filtered preconditioned $0.22 \mu \mathrm{m}$ membrane filter to prevent interference from particulates. All samples were detected well inside the $15 \mathrm{~min} / \mathrm{sample}$ run time. Samples were filtered through a $0.45 \mu \mathrm{m}$ Polyether-sulphone membrane filter (Gelman Sciences Acrodiscs) prior to analysis. The system was operated at $1.0 \mathrm{~mL} / \mathrm{min}$ and $30^{\circ} \mathrm{C}$, with $200 \mu \mathrm{L}$ injections and detection at $260 \mathrm{~nm}$. The mobile phase was degassed for 30 minutes in an ultrasonic bath prior to use. The system was calibrated using polystyrene sulphonates (PSS) (Polysciences, NJ, USA). $1 \mathrm{gL}^{-1}$ standards of 35, 18, 8 and 4.6 using polystyrene sulphonates (PSS) (Polysciences, $\mathrm{NJ}$, $\mathrm{USA}$ ). $1 \mathrm{gL}$ standards of $35,18,8$ and 4.6 an acetone solution $(1 \%)$ were used to determine the column's void volume and total permeation an acetone solution (1\%) were used to determine the column's void volume and total permeation
volumes, respectively. The PSS's were detected at $224 \mathrm{~nm}$, the acetone at $280 \mathrm{~nm}$ and the Blue volumes, respectively.
Dextran at $260 \mathrm{~nm}$.

Liquid Chromatography - Organic Carbon Detection (LC-OCD). LC-OCD consists of three size exclusion chromatography columns which divide the organic carbon into several fractions as a function of size, but also hydrophobic and ionogenic characteristics (39-41). A sample of up to 3 $\mathrm{mL}$ is injected into the instrument and filtered in-line with a $0.45 \mu \mathrm{m}$ filter. The deposit on the filter is backwashed after 5 minutes and directly anolysed wi particulate organic carbon (POC) content. The organic carbon detector used is based on a thin film reactor principle ("Gräntzel" type). The inorganic carbon is removed by a stripping process in the top of the reactor. The organic carbon is oxidised to $\mathrm{CO}_{2}$ by UV radiation at $185 \mathrm{~nm}$. This method is more efficient than the persulphate method, which was used for routine analysis (see (42) for oxidation efficiencies). The $\mathrm{CO}_{2}$ was analysed using non-dispersive infrared detection. The detection limits are in the low $\mu \mathrm{gL}^{-1}$ concentrations (43). UV absorbance was also determined in parallel. CDOC is the chromatographable (i.e. hydrophilic and amphiphilic) fraction of DOC Results were calculated using peak area. HOC is the hydrophobic fraction. The humic substances peak was used for molecular weight determination by fitting a symmetrical Poisson distribution to the peak, which allows determination of average weight $\mathrm{MW}(\mathrm{Mw})$ and average number $(\mathrm{Mn})$. The Mw/Mn ratio gives an indication of the width of the size distribution characteristics (39-41).

$\mathrm{Mw} / \mathrm{Mn}$ ratio gives an indication of the width of the size distribution characteristics (39-41).
Zeta Potential of Membranes. The streaming potential of membranes used was measured using a Brookhaven Instruments Corp. (Holtsville, NY, USA) BI-EKA commercial instrument which has a crossflow slit geometry. Childress and Elimelech (44) and Elimelech et al. (45) described the measuring cell and the principle in detail. The streaming potential, from which the zeta potential can be calculated with the Helmholtz-Smoluchowski equation, was measured in the presence of 1 $\mathrm{mmol} \mathrm{L}{ }^{-1} \mathrm{KCl}$.

\section{Results and Discussion}

Membrane Characterisation. The membrane surface potential is shown as a function of $\mathrm{pH}$ in Figure 1. The surface potential at $\mathrm{pH} 8$ is also given in Table 2, where membrane characteristics such as MWCO, estimated pore radii, pure water flux, permeability and membrane resistance are summarised. The membranes have a point of zero charge between $\mathrm{pH} 3$ and $\mathrm{pH} 4$. No relationship between oberved MWCO and surface charge is apparent. The results contradict the work Braghetta (46), who stated that regenerated cellulose membranes are uncharged. However, Clark and Jucker (47) reported regenerated cellulose membranes to be charged. UF is believed to reject principally on a size exclusion basis. However, as described later, the $3 \mathrm{kDa}$ and $5 \mathrm{kDa}$ membranes have a very similar rejection for the charged organic molecules. This can be attributed to charge interactions, as the $5 \mathrm{kDa}$ membrane has the more negative charge.

The molecular weight cut-off (MWCO) was specified by the manufacturer based on dextran experiments. The nominal pore radii, estimated from the MWCO using the relation given by Worch (48), range from 1 to $10 \mathrm{~nm}$. Since this correlation is based on dextran rejection it does not account for variations in retention as a function of molecular shape. In further work, it would be worthwhile for variations in retention as a function of molecular shape. In further work, it would be worthwhile
to investigate the MWCO which would be obtained when calibrating the membranes with PSS to investigate the MWCO which would be obtained when calibrating the memb
standards for a comparison of methods with identical and well defined compounds.

Fractionation Experiments. The effect of $\mathrm{pH}$, ionic strength, organic concentration, calcium concentration, and organic type on organic fractionation were investigated. The ionic strength influences DOC rejection considerably (see Figure 2). DOC rejection decreases by up to $20 \%$ when 
the $\mathrm{NaCl}$ concentration increases from 1.7 to $60 \mathrm{mmol} \mathrm{L}^{-1}$ (corresponding to a conductivity increase from 0.35 to $7.7 \mathrm{mScm}^{-1}$ ). The effect of ionic strength on DOC rejection may be attributed to the increased coiling that these large organic molecules undergo as shielding of functional groups occurs with increasing ionic strength (49). The functional groups make the molecules stretch to occurs with increasing ionic strength (49). The functional groups make the molecules stretch to
linear orientation at low ionic strength and at high ionic strength these molecules curl up and eventually aggregate (which may lead to an increase in rejection as shown by Aoustin et al. ([Aoustin, 2000 \#334])). Repulsive electrostatic interactions between a charged molecule and a charged membrane also decrease at higher ionic strength, allowing a closer approach of the organic molecules to the membrane surface and more facile entrainment of these molecules in permeate flowing through the membrane. It should be noted here that this charge effect is only expected if the size of the organics (33) reported that flexible linear molecules pass more easily through porous membranes than their spherocolloidal counterparts. This contradicts the results observed here and may indicate that other effects such as solute-membrane electrostatic interactions play a role.

The $\mathrm{pH}$ affects the charge of the organic molecules, and potentially (like the ionic strength) their shape and size. However, Ghosh and Schnitzer (49) stated that at low organic concentrations (such as the ones used here or as are common in natural waters) the effect of $\mathrm{pH}$ is much less significant than that of ionic strength. This is confirmed here with the results shown in Figure 3A and B. The effect of $\mathrm{pH}$, both at low and high ionic strength, is minimal and probably within experimental error effect of $\mathrm{pH}$, both at low and high ionic strength, is minimal and probably within experimental error
(estimated at 5\%). This could be due to a coupling of two phenomena with opposite effects since, (estimated at 5\%). This could be due to a coupling of two phenomena with opposite effects sice
with increasing $\mathrm{pH}$, the organics have a linear flexible shape, but also a more negative charge.

Figure 4 shows that DOC rejection in solutions with ionic strength of $20 \mathrm{mmol} \mathrm{L}^{-1} \mathrm{NaCl}$ is minimally affected by DOC concentration in the range 15 to $60 \mathrm{mgL}^{-1}$. However, fractionation of natural organics is often carried out on water samples of different origin or even concentrates. As shown above, if unpurified concentrates with varying ionic strength are treated, rejection varies significantly. This result is relevant when samples are preconcentrated - if organics are concentres with salts or regenerated from a resin at increased ionic strength, then their size characteristics
determined with UF will be different from those in low ionic strength solutions.

Calcium screens the charge on organic molecules in the same way that any salt does and it can also form complexes with organics or lead to aggregation of organic colloids. All these interactions will affect the organic size. Therefore, in waters containing different amounts of calcium, the size of otherwise identical organics may appear different. While as a general trend, the organic rejection decreases with calcium concentration (Figure 5), the effect observed is relatively small. Aoustin $e$ effects counterat each other - the reduced mow medium concentration and the apparent increase in size due to enhanced aggregation at high concentration. Schäfer (42) showed a clear increase in organic retention with increasing calcium concentration during UF. In the relatively short fractionation experiments this was not confirmed. The changes in DOC rejection with change in calcium concentration necessitate further investigation, possibly at higher calcium concentrations, to properly elucidate the effects of this divalent cation. The need for further investigation of the role of calcium is also highlighted by the effects of organics on retention of calcium shown in Table 3. In the absence of organics, calcium ions are only retained to any significant extent by the small pore size membranes (possibly as a result of the hydrated cation radius, which is $0.2-0.3 \mathrm{~nm}$ versus pore radii of 0.9 and $1.4 \mathrm{~nm}$ for the $1 \mathrm{kDa}$ and $3 \mathrm{kDa}$ membranes, respectively). In the presence of organic compounds, calcium is extensively retained even by the more porous membranes though considerable scatter in results is observed. This increased retention presumably arises as a result of increased interaction between calcium and retained organic molecules - either through electrostatic association or formation of metal-organic complexes. The interaction between metals and humic substances remains poorly understood and justifies further investigations.

UF fractionation results for the different organics used are presented in Figure 6. The rejection of the hydrophilic NOM fraction is low for all membranes; even the $1 \mathrm{kDa}$ membrane reaches only $67 \%$ rejection. Overall, the rejection of IHSS HA is the highest. The $1 \mathrm{kDa}, 3 \mathrm{kDa}$, and $5 \mathrm{kDa}$ membranes exhibit a very similar rejection behaviour and the pattern of rejection of organics is identical. The average rejection is about $80 \%$ in these cases. It has to be noted here, however, that the hydrophilic fraction has, due to the fractionation method used, an increased ionic strength (see Table 1). As discussed earlier, this may be a factor accounting (at least in part) for the observed lower rejection of this fiaction. For the $10 \mathrm{kDa}$ me $\mathrm{kDa}$ membrane. The greatest difference in rejection occurs between the $10 \mathrm{kDa}$ and the $30 \mathrm{kDa}$ membrane. Rejection drops to about $10 \%$ for the $30 \mathrm{kDa}$ membrane, followed by rejections near zero by the $100 \mathrm{kDa}$ membrane (results not shown).

UF membranes are generally believed not to retain ions (as opposed to nanofiltration membranes). However, some authors have reported ion rejection (50). Cations, especially multivalent cations and trace metals interact with humic substances (51),(52) and these inorganics would consequently be retained with that organic fraction. Again, further work is needed to understand this interaction in detail.

The $\mathrm{UV}_{254 \mathrm{~nm}} / \mathrm{DOC}$ ratio is thought to reflect the aromaticity of a sample. The higher the ratio, the The $\mathrm{UV}_{254 \mathrm{~nm}} / \mathrm{DOC}$ ratio is thought to reflect the aromaticity of a sample. The higher the ratio, the
more aromatic is the organic. As can be seen from Figure 7 a higher ratio is observed in the more aromatic is the organic. As can be seen from Figure 7 a higher ratio is observed in the
permeates from higher MWCO membranes suggesting a clear relation between organics molecular permeates from higher MWCO membranes suggesting a clear relation between organics molecular
weight and aromaticity; i.e. larger organics are more aromatic and are retained more effectively on the smaller pore size membranes.

Comparison of UF fractionation and Size Exclusion Chromatography (SEC). All samples from fractionation experiments were analysed with size exclusion chromatography (SEC) to determine if there is a separation based on size. The SEC technique was optimised to reduce charge interactions between the organics and the column. This resulted in an analysis at relatively high ionic strength Selected results are presented here for various ionic strengths.

Figure $8 \mathrm{~A}$ to Figure $8 \mathrm{~F}$ show the SEC results for the feed containing NOM concentrate and $1 \mathrm{kDa}$, $3 \mathrm{kDa}, 5 \mathrm{kDa}, 10 \mathrm{kDa}$, and $30 \mathrm{kDa}$ permeate samples, respectively, in $1.7 \mathrm{mmol} \mathrm{L}^{-1}, 20 \mathrm{mmol} \mathrm{L}^{-1}$, and $60 \mathrm{mmol} \mathrm{L}^{-1} \mathrm{NaCl}$. The $\mathrm{y}$-axis in the SEC graphs is the concentration of organic matter in the sample, as determined by UV absorbance. This measurement is selective as it preferentially measures larger, more aromatic compounds. Unfortunately, at the time when this research was carried out, DOC analysis was unavailable. Such analysis is difficult as the concentrations are very low. As a result small, non-UV-absorbing compounds are lost in the SEC analysis.

The leftmost peak (lowest molecular weight, 100Da) is the 'salt peak' which includes salts from samples and the buffer. The different figures identify an overlay of three major peaks in the NOM sample, which become more or less abundant in the different permeates, particularly as a function of ionic strength and membrane pore size.

For the $1 \mathrm{kDa}$ membrane (Figure $8 \mathrm{~B}$ ), the $\mathrm{UV}$-absorbing material in the permeate sample is obviously lower than that found in permeates for higher MWCO membranes. Two organic peaks are visible, one at 400-500 Da and ather at 700-800 Da. The smaller MW peak is the highest are visible, 列 most likely that these low molecular weight compounds are neutral and amphiphilic in character This fraction was identified to be about $13.2 \%$ of DOC (42), however its UV absorbance is low ( $2.8 \%$ of the total). This means that this fraction is underestimated with the SEC method. 
For the $3 \mathrm{kDa}$ membrane (Figure $8 \mathrm{C}$ ) the same peaks are visible, but now the 700-800 Da peak is the highest. Interestingly, for the $5 \mathrm{kDa}$ membrane (Figure $8 \mathrm{D}$ ), this effect is partly reversed, which may suggest that the 700-800 Da peak may be a charged fraction which is retained more by the more charged $5 \mathrm{kDa}$ membrane. The trend continues with the $10 \mathrm{kDa}$ membrane (Figure $8 \mathrm{E}$ ); the more charged $5 \mathrm{kDa}$ membrane. The trend continues with the $10 \mathrm{kDa}$ membrane (Figure 8E); the
peak at $400-500 \mathrm{Da}$ is still present but the peak at $700-800 \mathrm{Da}$ dominates and is now accompanied peak at $400-500 \mathrm{Da}$ is still present but the peak at $700-800 \mathrm{Da}$ dominates and is now accompanied
by a shoulder at around $1000 \mathrm{Da}$. In the $30 \mathrm{kDa}$ permeates (Figure $8 \mathrm{~F}$ ) this 'new' peak clearly dominates and the sample is not very different from the feed samples (Figure 8A).

In assessing the effect of ionic strength it should be noted that the results of SEC analysis of the feed samples at different ionic strengths are identical. This means that any 'size' difference which the different ionic strength may induce, is fully reversible once the samples are injected into the relatively strong ionic environment of the SEC analysis. Alternatively, it could be argued that ionic strength change is having a negligible effect on size and/or shape of the organic molecules with strength change is having a negligible effect on size and/or shape of the organic molecules with
effects of ionic strength on the ultrafilterability of organic molecules being due to alteration in charge screening. These two effects are difficult to separate; if anything, the UF results favour a charge explanation. The SEC results confirm that the concentration of organics in the permeate increases with an increase in ionic strength, in accord with the observed decrease in rejection in the UF fractionation on ionic strength increase.

For the $1 \mathrm{kDa}$ membrane the low MW organic peak dominates for all ionic strengths, whereas for the $3 \mathrm{kDa}$ membrane this changes. At high ionic strength the two peaks are identical, whereas at low ionic strength the low MW peak is higher. This shows that a higher ionic strength allows more low ionic strength the low MW peak is higher. This shows that a higher ionic strength allows more
of the larger compounds to pass through the membrane. Above it was suggested that the low MW compounds may be retained more by the $5 \mathrm{kDa}$ membrane due to charge effects. If this was the case then the same explanation applies here. The $5 \mathrm{kDa}$ membrane shows more or less the same trend as the $3 \mathrm{kDa}$ membrane. For the $10 \mathrm{kDa}$ membrane the same shift is observed with the increase in ionic strength, whereas the $30 \mathrm{kDa}$ membrane shows no shift (it does not retain organics at all).

Overall, the apparent molecular weight measured with SEC is smaller than that implied by UF fractionation. There are several factors contributing to this. First of all, the ionic strength of the eluent is very high in the SEC method possibly leading to coiling of the molecules. Secondly, eluent is very high in the SEC method possibly leading to coiling of the molecules. Secondly,
charge interactions may cause a higher rejection by the UF membranes than implied by the nominal charge interactions may cause a higher rejection by the UF membranes than implied by the nominal
MWCO alone. (That some charge effects are evident has been discussed above). Thirdly, the calibration of the methods is very different. While the MWCO of the UF membranes was determined using dextran, the SEC was calibrated with a range of compounds. In neither case do the compounds necessarily reflect the characteristics of humic substances and NOM. It should be noted that the feed solutions had identical peak heights for the three experiments, which clearly demonstrated the different retentions achieved as a function of salt concentration

Chemical Analysis of the Natural Organics and UF Fractions using LC-OCD. The six natural organics investigated in this study (IHSS FA and HA, NOM and NOM fractions NOM-HA, NOMFA and NOM-Hyd) were analysed using LC-OCD as was the NOM feed sample and the five permeates obtained from filtration through the various pore size UF membranes. The average molecular weights for the various natural organics, obtained by fitting a Poisson distribution to the LC-OCD humics peak (see the LC-OCD output for the feed sample in Figure 10), are shown as functions of the organics aromaticity in Figure 9. The mass average molecular weight of the organics investigated follows the order IHSS HA $>$ NOM HA $>$ IHSS FA $>$ NOM $>$ NOM FA $>$ NOM hydrophilic fraction with sizes ranging from 2747 to 970 Da. These molecular weights correspond to molecular radii of 1.35 to $0.79 \mathrm{~nm}(43)$.

The results given in Figure 10 for the fractionation samples (NOM concentrate, fractionated at 20 $\mathrm{mmol} \mathrm{L}{ }^{-1} \mathrm{NaCl}$ ) show three distinct components of NOM in the samples; humics, HS-hydrolysates and low molecular mass acids. In the feed sample some polysaccharides are present which is typical for a surface water source. The polysaccharides peak is very small and not apparent even in the $30 \mathrm{kDa}$ permeate. The UF membranes reduce the different compounds to varying extents. The humics are retained most with an overall shift towards smaller sizes (peak maximum drifts towards higher elution times). This is also evident from the lower molecular weights of these fractions and lower UV/DOC ratios as shown in Table 4. However, the molecular weights measured are not related to the MWCO of these membranes. Values are much smaller and comparable to SEC results. Comparing the peaks of LC-OCD and SEC, it can be assumed that the largest SEC peak is attributable to the humics. This peak was reduced most in size with fractionation. The second peak seen in the SEC graphs (Figure 8) is most likely related to the low molecular mass acids. These peaks and their changes in peaks in the LC-OCD and SEC analyses and further work is required to understand the relative
contributions of the various organic components to the observed peaks.

\section{Implications to "size" analysis of natural organics by membrane techniques.}

The major implication of the results presented here is that UF should not be applied for quantitative "size" analysis unless operated under particular, well-defined conditions. Overall rejection depends largely on molecule conformation and membrane-solute charge interactions. If operated under conditions appropriate to water treatment, the results of UF fractionation can give more information than techniques such as size exclusion chromatography since information of direct applicability to the treatment process, such as the MWCO required to achieve significant removal, can be obtained relatively simply.

\section{Acknowledgements}

Dr Georg Hagmeyer (IWW, Mülheim, Germany), Dr Chris Hepplewhite (AWQC, Adelaide, Australia), and Dr Stefan Huber (DOC Labor, Karlsruhe, Germany) are thanked for streaming potential measurements, SEC, and LC-OCD analysis, respectively. Useful comments from Prof Mark Benjamin (University of Washington, Seattle, USA) are greatly appreciated.

The CRC for Water Quality and Treatment is acknowledged for providing project funding and a scholarship for A.I. Schäfer. An OPRS scholarship from the Australian Government is also acknowledged.

\section{Literature Cited}

(1) Goldsmith, R. L. Ind. Eng. Chem. Fundam. 1971, 10, 113-120.

(2) Jucker, C.; Clark, M. M. Journal of Membrane Science 1994, 97, 37-52

(3) Hazlett, T. American Society for Testing and Materials, 1990.

(4) Readman, J. Biotechnology 1991, 9, 941-946.

(5) De Nobili, M.; Fornasier, F. in Humic Substances in the Global Environment and Implications on Human Health (eds. Senesi, N. Miano, T. M.) Elsevier Science, 1994, 269-272.

(6) Küchler, I. L.; Miekeley, N.; Forsberg, B. R. The Science of the Total Environment 1994, 156, 207 216.

(7) Mazid, M. A. Separation Science and Technology 1988, 23, 2191-2210.

(8) Belin, C.; Quellec, C.; Lamotte, M.; Ewald, M.; Simon, P. Environmental Technology 1993, 14, 1131-1144.

(9) Shaw, P. J.; de Haan, H.; Jones, R. I. Environmental Technology 1994, 15, 753-764

(10) Burba, P.; Aster, B.; Nifant'eva, T.: Shkinev, V.: Spivakov, B. Y. Talanta 1998, 45, 977-988.

(11) Buffle, J.; Deladoey, P.; Haerdi, W. Analytica Chimica Acta 1978, 101, 339-357.

(12) Crum, R. H.; Murphy, E. M.; Keller, C. K. Water Research 1996, 30, 1304-1311.

(13) Aiken, G. R. Environmental Science \& Technology 1984, 18, 978-981. 
Schäfer, A.I. ; Mauch, R. ; Fane, A.G. ; Waite, T.D. (2002) Charge Effects in the Fractionation of Natural Organics using Ultrafiltration, Environmental Science \& Technology 36, 2572-2580. DOI: $10.1021 / \mathrm{es} 0016708$

(14) Amy, G. L.; Collins, M. R.; Kuo, C. J.; King, P. H. Journal AWWA, Research and Technology 1987, Jan, $43-49$.

(15) Reinhard, M. Environ. Sci. Technol. 1984, 18, 410-415. 1992, June, 67-75

(17) Hepplewhite, C. Australian Water Quality Centre, Bolivar, SA, 1995

(18) Collins, M. R.; Amy, G. L.; Steelink, C. Environmental Science \& Technology 1986, 20, 1028-1032

(19) Aster, B.; Burba, P.; Broekaert, J. A. C. Fresenius J. Analytical Chemistry 1996, 354, 722-728.

(20) Wershaw, R. L.; Aiken, G. R. in Humic Substances, in Soil, Sediment, and Water (eds. Aiken, G. R.; McKnight, D. M.;Wershaw, R. L. MacCarthy, P.) John Wiley \& Sons, Inc., 1985, 477-492.

(21) De Nobili, M.; Fornasier, F. European Journal of Soil Science 1996, 47, 223-229.

(22) Pettersson, C.; Ephraim, J.; Allard, B. Organic Geochemistry 1994, 21, 443-451.

(23) Huber, S. A. (unpublished),

(24) Specht, C. H.; Frimmel, F. H. Environmental Science \& Technology 2000, 34, 2361-2366.

(25) Aoyama, M. Soil Sci. Plant Nutr. 1996b, 42, 21-30.

(25) Aoyama, M. Soil Sci. Plant Nutr. 1996b, 42, 21-30.

(27) Mori, S. Anal Chem 1988, 60,1125-1128.

(28) Becher, G.; Carlberg, G. E; Gjessing, E. T. H Hongslo, J. K. Monarca, S. Environ Sci. Technol 1985, $19,422-426$

(29) Perminova, I. V.; Frimmel, F. H.; Kovalevskii, D. V.; Abbt-Braun, G.; Kudryavtsev, A. V.; Hesse, S. Water Research 1998, 32, 872-881.

(30) Leenheer, J. A. in Humic Substances, in Soil, Sediment, and Water (eds. Aiken, G. R.;McKnight, D. M.;Wershaw, R. L. MacCarthy, P.) John Wiley \& Sons, Inc., 1985, 409-429.

(31) Ephraim, J. H.; Pettersson, C.; Allard, B. Environment International 1996, 22, 475-483.

(32) Kwak, J. C. T.; Nelson, R. W. P. Geochimica and Cosmochimica Acta 1977, 41, 993-996.

(33) Staub, C.; Buffle, J.; Haerdi, W. Analytical Chemistry 1984, 56, 2843-2849.

(35) Averett, R. C.; Leenheer, J. A.: McKnight, D. M. Thorn. K. A. U.S. Geological Survey, 1989.

(36) Leenheer, J. A. Environmental Science \& Technology 1981, 15, 578-587.

(36) Leenheer, J. A. Environmental Science \& Technology 1981, 15, 578-587.
(37) Leenheer, J. A. in Natural Organic Matter Workshop; 4 Poitiers, France, 1996.

(37) Leenheer, J. A. in Natural Organic Matter Workshop; 4 Poitiers, France, 1996.
(38) Chin, Y. P.; Aiken, G.: Oloughlin, E. Environmental Science and Technology 1994, 28, 1853-1858.

(38) Chin, Y. P.; Aiken, G.; Oloughlin, E. Environmental Science and Technology 1994, 28, 1853-185

(40) Huber, S. A.; Frimmel, F. H. Fresenius Journal of Analytical Chemistry 1992, 342, 198-200. 503 .

(41) Huber, S. A. Ultrapure Water 1998, , 16-20.

(42) Schäfer, A. I. Natural Organic Matter Removal using Membranes: Principles, Performance and Cost

(43) Frimmel, F. H. Journal of Contaminant Hydrology 1998, 35, 201-216.

(44) Childress, A. E.; Elimelech, M. Journal of Membrane Science 1996, 119, 253-268.

(45) Elimelech, M.; Chen, W. H.; Waypa, J. J. Desalination 1994, 95, 269-286.

(46) Braghetta, A. The influence of solution chemistry and operating conditions on nanofiltration of charged and uncharged organic macromolecules University of North Carolina: Chapel Hill, 1995.

(47) Clark, M. M.; Jucker, C. in Proc. of AWWA Membrane Technology Conf.; 259-272 Baltimore, 1993.

(48) Worch, E. Vom Wasser 1993, 81, 289-297.

(49) Ghosh, K.; Schnitzer, M. Soil Science 1980, 129, 266-276.

(50) Küchler, I. L.; Miekeley, N. The Science of the Total Environment 1994, 154, $23-28$.

(51) Klein, R.; Weitz, D. A.; Lin, M. Y.; Lindsay, H. M.; Ball, R. C.; Meakin, P. Progress in Colloid and Polymer Science 1990, 81, 161-168.

(52) Frimmel, F. H.; Huber, L. Environment International 1996, 22, 507-517.

\section{Tables}

Table 1 Cation content of organics used. The salt content is per amount of DOC due to the stock solution concentration. Values in brackets are per $100 \mathrm{mgL}^{-1}$ DOC, thus mg cations per $100 \mathrm{mg}$ DOC

\begin{tabular}{|c|c|c|c|c|c|c|}
\hline $\begin{array}{l}\mathrm{ImgL}^{-} \\
\left.{ }^{1}\right]\end{array}$ & IHSS HA & IHSS FA & NOM & NOM HA & NOM FA & $\begin{array}{c}\text { NOM } \\
\text { Hydrophilic }\end{array}$ \\
\hline DOC & 100 & 100 & 100 & 250.3 & 114.5 & 22.1 \\
\hline \multirow[t]{2}{*}{$\mathrm{Al}$} & 0.10 & 0.02 & 0.58 & $0.24(0.10)$ & 0.07 & $0.47(2.13)$ \\
\hline & $(0.10)$ & $(0.02)$ & $(0.58)$ & & $(0.06)$ & \\
\hline \multirow[t]{2}{*}{$\mathrm{Ca}$} & 0.22 & $0(0)$ & 62.6 & $0.61(0.24)$ & 0.24 & 48.6 \\
\hline & $(0.22)$ & & (62.6) & & $(0.21)$ & (219.9) \\
\hline \multirow[t]{2}{*}{$\mathrm{Fe}$} & 0.11 & $0(0)$ & 1.41 & $0.46(0.18)$ & 0.36 & $1.2(5.43)$ \\
\hline & $(0.11)$ & & (1.41) & & $(0.31)$ & \\
\hline \multirow[t]{2}{*}{$\mathrm{Na}$} & 1.52 & 0.23 & 296 (296) & $3.16(1.26)$ & 3.54 & 244 \\
\hline & (1.52) & $(0.23)$ & & & (3.09) & (1104.1) \\
\hline \multirow[t]{2}{*}{ K } & 0.55 & 0.41 & 52.4 & $2.16(0.86)$ & 1.19 & $1.43(6.47)$ \\
\hline & $(0.55)$ & $(0.41)$ & (52.4) & & (1.04) & \\
\hline
\end{tabular}


Schäfer, A.I. ; Mauch, R. ; Fane, A.G. ; Waite, T.D. (2002) Charge Effects in the Fractionation of Natural Organics using Ultrafiltration, Environmental Science \& Technology 36, $2572-2580$. DOI: $10.1021 / \mathrm{es} 0016708$

Table 2 Molecular weight cut-off, pore size, pure water flux, operating pressure and surface charge of the UF membranes used.

\begin{tabular}{cccccccc}
\hline $\begin{array}{c}\text { Membrane } \\
\text { Type }\end{array}$ & $\begin{array}{c}\text { MWCO } \\
{[\mathrm{kDa}]}\end{array}$ & $\begin{array}{c}\text { Pore Radii } \\
{[\mathrm{nm}]^{*}}\end{array}$ & $\begin{array}{c}\text { 軼 } \\
{[\mathrm{kPa}]}\end{array}$ & $\begin{array}{c}\text { Pure Water } \\
\text { Flux } \\
{\left[\mathrm{Lm}^{-2} \mathrm{~h}^{-1}\right]}\end{array}$ & $\begin{array}{c}\text { Permeability } \\
{\left[\mathrm{Lm}^{-2} \mathrm{~h}^{-1} \mathrm{bar}^{-1}\right]}\end{array}$ & $\begin{array}{c}\text { Membrane } \\
\text { Resistance } \\
{\left[\mathrm{m}^{-1}\right]}\end{array}$ & $\begin{array}{c}\text { Surface } \\
\text { Charge }(\mathrm{pH} 8) \\
{[\mathrm{mV}]}\end{array}$ \\
\hline PLAC & 1 & 0.94 & 300 & $15 \pm 2$ & 5.0 & $7.18 \cdot 10^{13}$ & -11.6 \\
PLBC & 3 & 1.42 & 300 & $22 \pm 2$ & 7.3 & $4.90 \cdot 10^{13}$ & -9.2 \\
PLCC & 5 & 1.91 & 300 & $28 \pm 3$ & 9.3 & $3.85 \cdot 10^{13}$ & -14.3 \\
PLGC & 10 & 2.59 & 300 & $65 \pm 5$ & 21.7 & $1.66 \cdot 10^{13}$ & -7.5 \\
PLTK & 30 & 4.81 & 100 & $390 \pm 20$ & 390 & $0.09 \cdot 10^{13}$ & -16.4 \\
PLHK & 100 & 9.10 & 100 & $1320 \pm 40$ & 1320 & $0.03 \cdot 10^{13}$ & -17.3 \\
\hline
\end{tabular}

calculated after Worch (48).
Table 3 Calcium rejection by the UF membranes in the absence and presence of organics $(20 \mathrm{mmol}$

$\mathrm{L}^{-1} \mathrm{NaCl}, 1 \mathrm{mmol} \mathrm{L} \mathrm{NaHCO}_{3}, 0.5 \mathrm{mmol} \mathrm{L}^{-1} \mathrm{CaCl}_{2}, \mathrm{pH}$ 7-8, $15 \mathrm{mg} / \mathrm{L}$ DOC).

\begin{tabular}{lccccc}
\hline Membrane [kDa] & 1 & 3 & 5 & 10 & 30 \\
\hline & & \multicolumn{5}{c}{ Calcium Rejection [\%] } \\
No organic & 13.1 & 13.5 & 1.9 & 2.5 & 2.8 \\
IHSS FA & 16.5 & 17 & 18.5 & 16.5 & 12.5 \\
IHSS HA & 14.5 & 14 & 10 & 14 & 5 \\
NOM FA & 18.5 & 15 & 10.5 & 10 & 3 \\
NOM HA & 18.5 & 18.5 & 8 & 13.5 & 5.5 \\
\hline
\end{tabular}


Schäfer, A.I. ; Mauch, R. ; Fane, A.G. ; Waite, T.D. (2002) Charge Effects in the Fractionation of Natural Organics using Ultrafiltration, Environmental Science \& Technology 36, $2572-2580$. DOI: $10.1021 / \mathrm{es} 0016708$

Table 4 Quantitative analysis of LC-OCD results of fractionated feed and permeate samples (20 mmol L ${ }^{-1} \mathrm{NaCl}, 1 \mathrm{mmol} \mathrm{L}^{-1} \mathrm{NaHCO}_{3}, 0.5 \mathrm{mmol} \mathrm{L}^{-1} \mathrm{CaCl}_{2}, \mathrm{pH}$ 7-8).

\begin{tabular}{|c|c|c|c|c|c|c|}
\hline Parameter & Feed & $30 \mathrm{kDa}$ & $10 \mathrm{kDa}$ & $5 \mathrm{kDa}$ & $3 \mathrm{kDa}$ & $1 \mathrm{kDa}$ \\
\hline Chromatographable Fraction (CDOC) [\%] & 71.6 & 98.2 & 95.0 & 88.7 & 82.9 & 86.0 \\
\hline Hydrophobic Fraction (HOC) [\%] & 28.2 & 1.6 & 4.9 & 11.1 & 17.0 & 13.7 \\
\hline Particulate Organic Carbon (POC) [\%] & 0.2 & 0.2 & 0.1 & 0.2 & 0.1 & 0.2 \\
\hline Humics [\% of CDOC] & 41.4 & 19.7 & 15.2 & 15.5 & 27.1 & 6.7 \\
\hline HS-Hydrolysates [\% of CDOC] & 14.6 & 6.0 & 6.5 & 9.6 & 23.2 & 4.8 \\
\hline $\mathrm{LMM}^{*}$ Acids [\% of CDOC] & 12.9 & 3.3 & 4.4 & 8.9 & 9.5 & 8.7 \\
\hline LMM" Neutrals and Amphophilics [\% of & 28.4 & 70.3 & 73.6 & 64.9 & 38.6 & 79.3 \\
\hline \multicolumn{7}{|l|}{$\mathrm{CDOC}]$} \\
\hline Polysaccharides [\% of CDOC] & 2.8 & 0.7 & 0.3 & 1.0 & 1.6 & 0.4 \\
\hline $\mathrm{M}_{\mathrm{W}}\left[\mathrm{gmol}^{-1}\right]$ & 972 & 952 & 793 & 751 & 724 & 716 \\
\hline $\mathrm{M}_{\mathrm{N}}\left[\mathrm{gmol}^{-1}\right]$ & 664 & 644 & 568 & 567 & 552 & 539 \\
\hline $\mathrm{M}_{\mathrm{W}} / \mathrm{M}_{\mathrm{N}}[-]$ & 1.46 & 1.48 & 1.40 & 1.32 & 1.31 & 1.33 \\
\hline $\mathrm{UV}_{254 \mathrm{~mm}} / \mathrm{OC}\left[\mathrm{Lmg}^{-1} \mathrm{~m}^{-1}\right]$ & 4.10 & 3.99 & 3.72 & 3.23 & 3.42 & 3.05 \\
\hline
\end{tabular}

LMM - Low Molecular Mass

\section{Figure Captions}

Figure 1 Zeta potential of the UF membranes in $1 \mathrm{mmol} \mathrm{L}^{-1} \mathrm{KCl}$.

Figure 2 DOC rejection as a function of ionic strength $\left(15 \mathrm{mgL}^{-1} \mathrm{NOM}\right.$ concentrate, $\left.\mathrm{pH} 7-8\right)$.

Figure 3 DOC rejection as a function of $\mathrm{pH}\left(15 \mathrm{mgL}^{-1} \mathrm{NOM}\right.$ concentrate, (A) $20 \mathrm{mmol} \mathrm{L}^{-1} \mathrm{NaCl}$,

(B) no $\mathrm{NaCl}$ added).

Figure 4 Effect of organic concentration on DOC rejection $\left(15 \mathrm{mgL}^{-1} \mathrm{NOM}\right.$ concentrate, $20 \mathrm{mmol}$

$\left.\mathrm{L}^{-1} \mathrm{NaCl}, \mathrm{pH} 7-8\right)$

Figure 5 Effect of calcium concentration on DOC rejection $\left(15 \mathrm{mgL}^{-1}\right.$ DOC NOM concentrate, 20 $\mathrm{mmol} \mathrm{L}{ }^{-1} \mathrm{NaCl}, 1 \mathrm{mmol} \mathrm{L}^{-1} \mathrm{NaHCO}_{3}, 0.5 \mathrm{mmol} \mathrm{L}^{-1} \mathrm{CaCl}_{2}, \mathrm{pH}$ 7-8).

Figure 6 Rejection of the organics by different UF membranes $\left(15 \mathrm{mgL}^{-1} \mathrm{DOC}, 20 \mathrm{mmol} \mathrm{L}^{-1} \mathrm{NaCl}\right.$, $\left.1 \mathrm{mmol} \mathrm{L}{ }^{-1} \mathrm{NaHCO}_{3}, 0.5 \mathrm{mmol} \mathrm{L}^{-1} \mathrm{CaCl}_{2}, \mathrm{pH} 7-8\right)$.

Figure 7 Effect of membrane type on $\mathrm{UV}_{254 \mathrm{~nm}} / \mathrm{DOC}$ ratio in permeates at different organic concentrations ( $15 \mathrm{mgL}^{-1} \mathrm{NOM}$ concentrate, $\left.20 \mathrm{mmol} \mathrm{L}^{-1} \mathrm{NaCl}, \mathrm{pH} 7-8\right)$.

Figure $8 \mathrm{SEC}$ results of feed (A) and permeates of the $1 \mathrm{kDa}(\mathrm{B}), 3 \mathrm{kDa}(\mathrm{C}), 5 \mathrm{kDa}(\mathrm{D}), 10 \mathrm{kDa}(\mathrm{E})$, and $30 \mathrm{kDa}(\mathrm{F}) \mathrm{UF}$ membranes at varied salt concentration $\left(15 \mathrm{mgL}^{-1} \mathrm{NOM}\right.$ concentrate).

Figure 9 Humification diagram for the natural organics as used in this study and other organics as reported by Huber (41).

Figure 10 Results of LC-OCD analysis of UF fractions and feed solution at $20 \mathrm{mmol} \mathrm{L}^{-1} \mathrm{NaCl}$ of NOM concentrate $\left(20 \mathrm{mmol} \mathrm{L}^{-1} \mathrm{NaCl}, 1 \mathrm{mmol} \mathrm{L}^{-1} \mathrm{NaHCO}_{3}, 0.5 \mathrm{mmol} \mathrm{L}^{-1} \mathrm{CaCl}_{2}, \mathrm{pH} 7-8\right)$ 
Schäfer, A.I. ; Mauch, R. ; Fane, A.G. ; Waite, T.D. (2002) Charge Effects in the Fractionation of Natural Organics using Ultrafiltration, Environmental Science \& Technology 36, $2572-2580$. DOI: $10.1021 / \mathrm{es} 0016708$
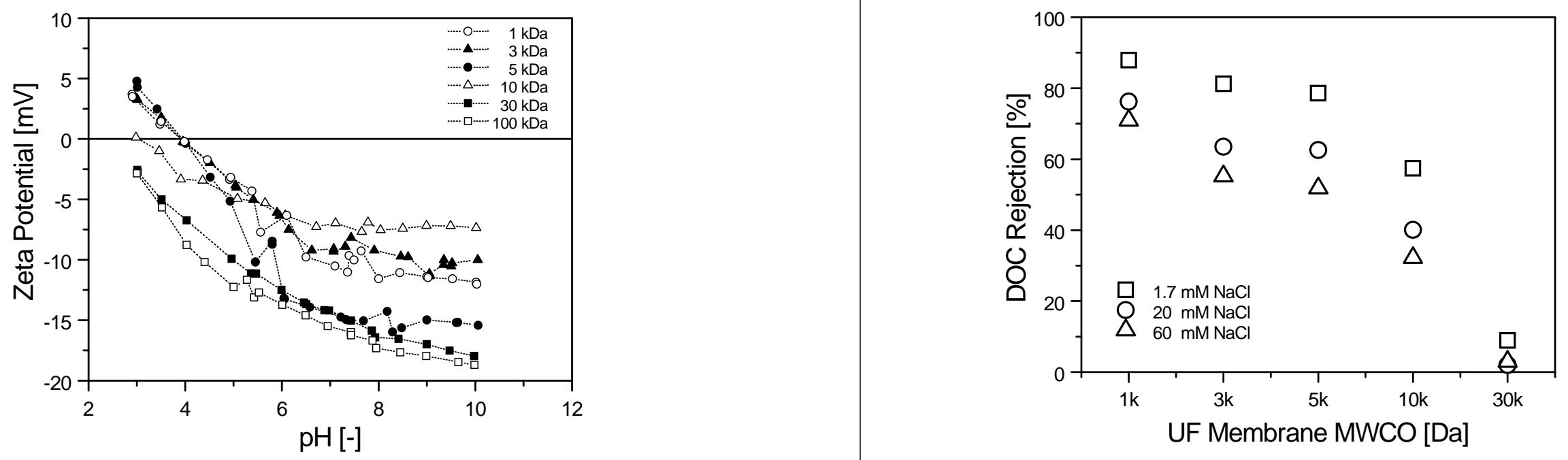

FIG 1

FIG 2 
Schäfer, A.I. ; Mauch, R. ; Fane, A.G. ; Waite, T.D. (2002) Charge Effects in the Fractionation of Natural Organics using Ultrafiltration, Environmental Science \& Technology 36, 2572-2580. DOI: $10.1021 / \mathrm{es} 0016708$
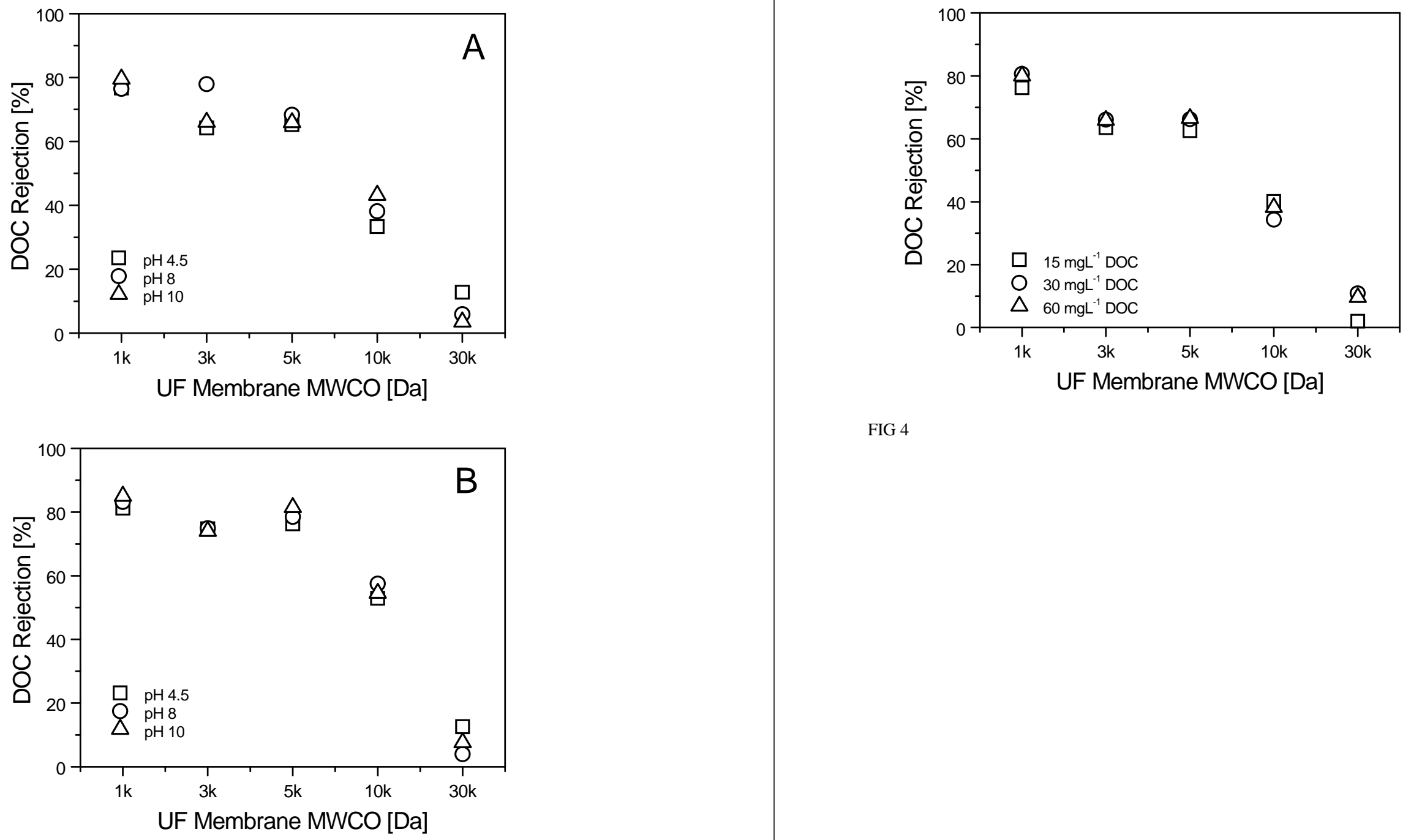

FIG 4

FIG 3 
Schäfer, A.I. ; Mauch, R. ; Fane, A.G. ; Waite, T.D. (2002) Charge Effects in the Fractionation of Natural Organics using Ultrafiltration, Environmental Science \& Technology 36, $2572-2580$. DOI: $10.1021 / \mathrm{es} 0016708$
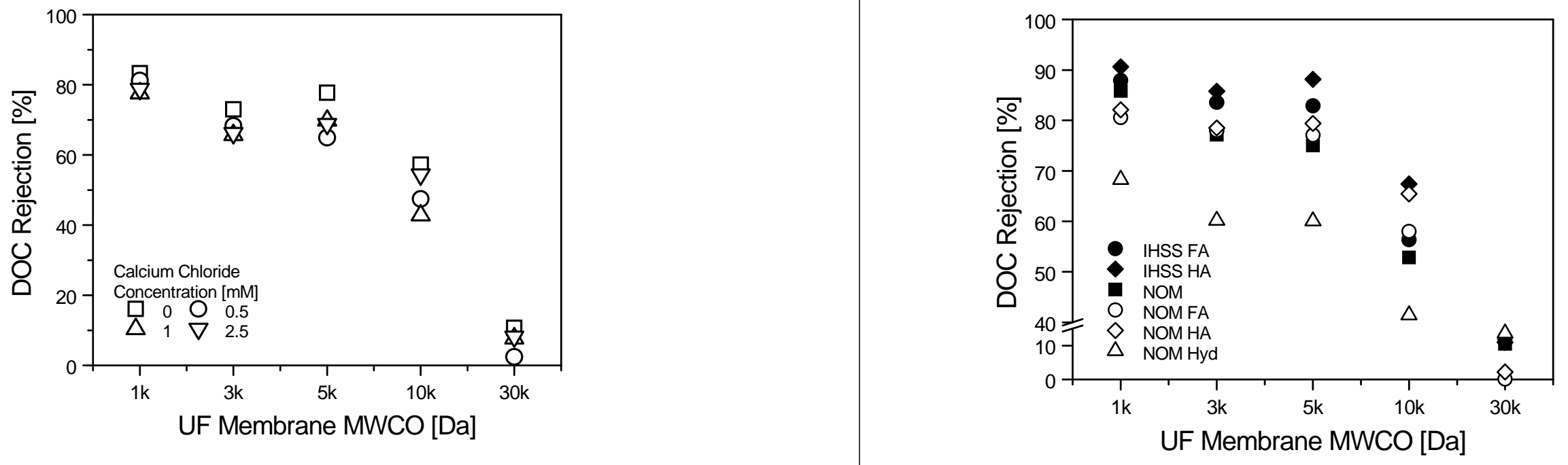

FIG 5

FIG 6 
Schäfer, A.I. ; Mauch, R. ; Fane, A.G. ; Waite, T.D. (2002) Charge Effects in the Fractionation of Natural Organics using Ultrafiltration, Environmental Science \& Technology 36, $2572-2580$. DOI: $10.1021 / \mathrm{es} 0016708$

FIG 8

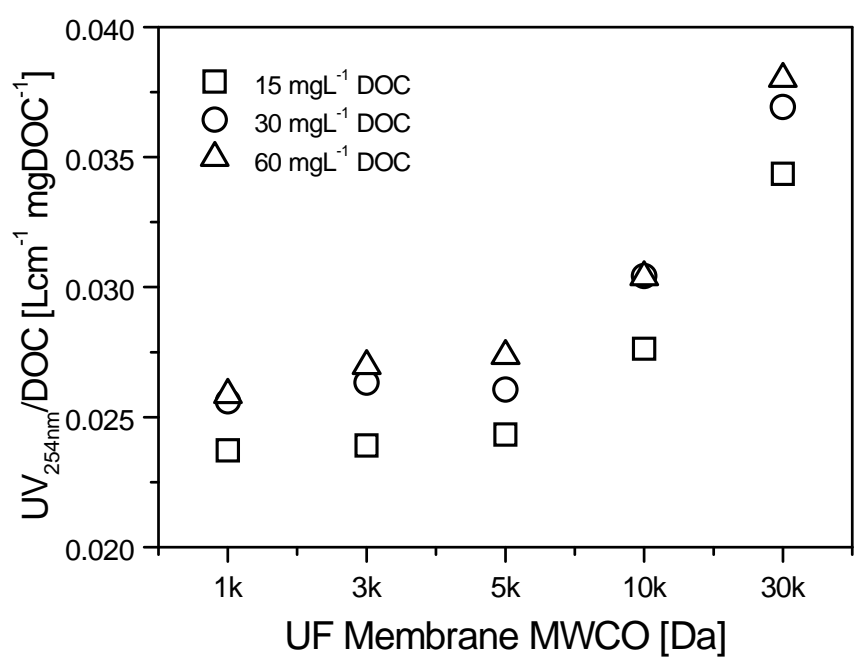

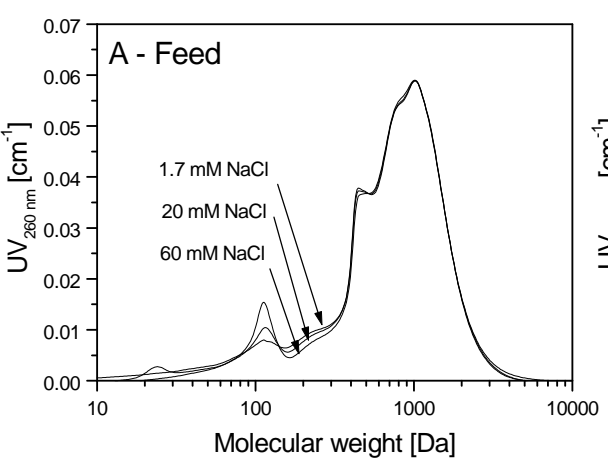
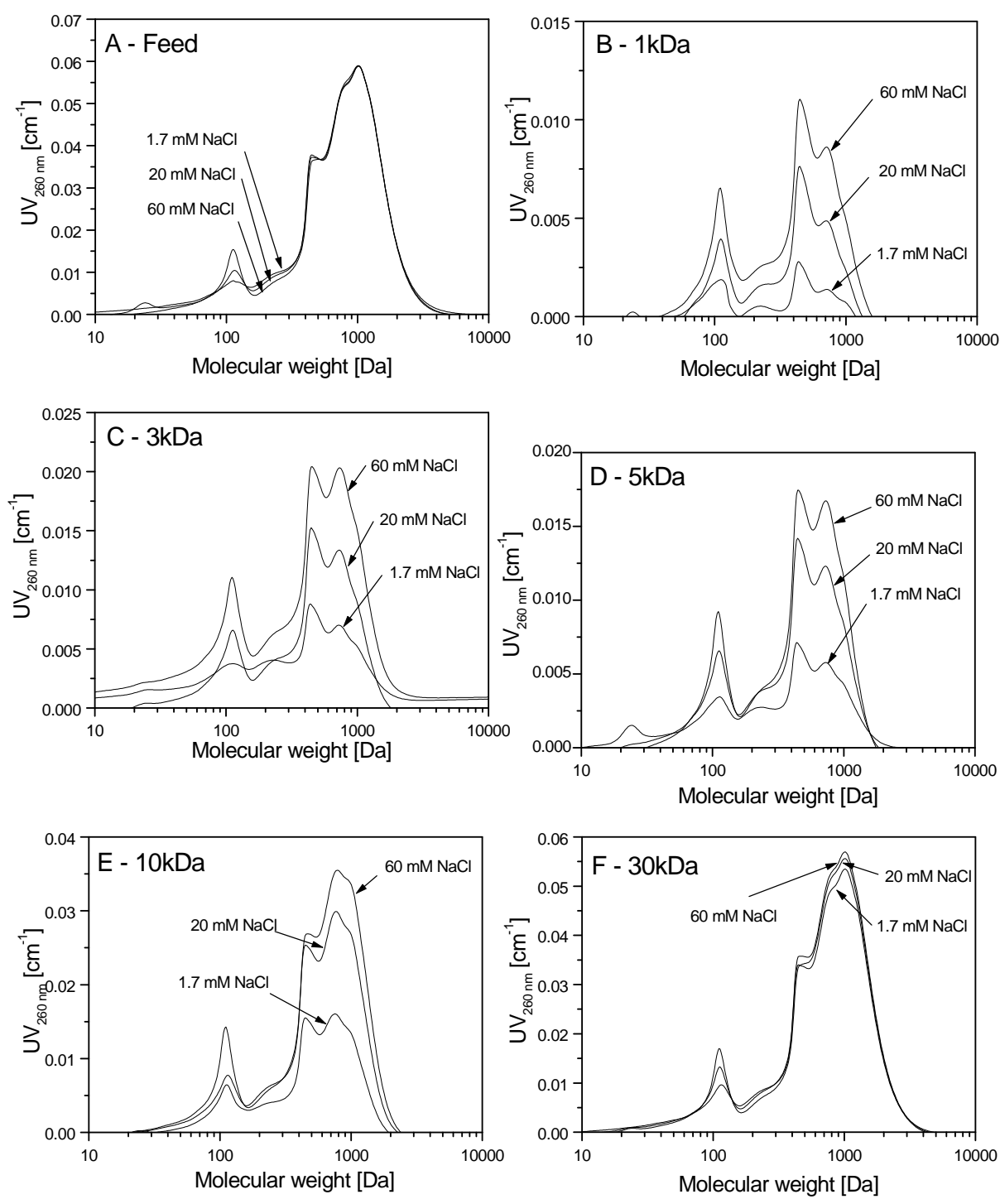
Schäfer, A.I. ; Mauch, R. ; Fane, A.G. ; Waite, T.D. (2002) Charge Effects in the Fractionation of Natural Organics using Ultrafiltration, Environmental Science \& Technology 36, $2572-2580$. DOI: $10.1021 / \mathrm{es} 0016708$
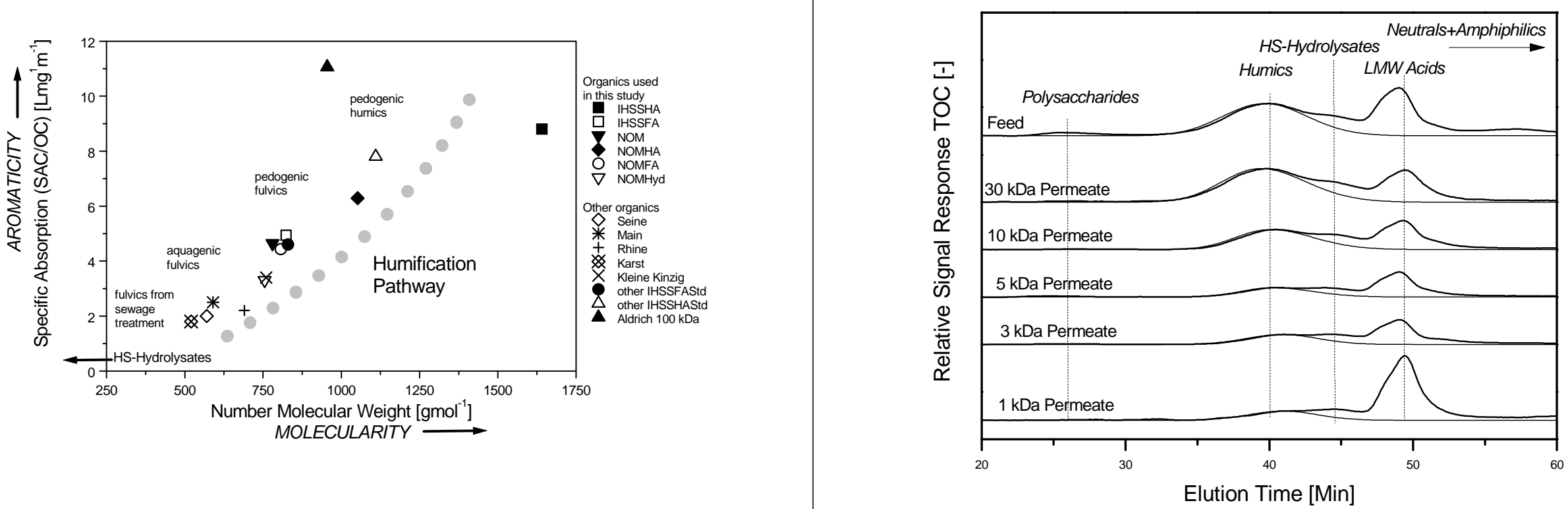